Article

\title{
Land and Landscape; Linking Use, Experience and Property Development in Urban Areas
}

\section{Gunilla Lindholm}

Planning and Management, Dept of Landscape Architecture, Swedish University of Agricultural Sciences, 23053 Alnarp, Sweden; gunilla.lindholm@slu.se

Received: 7 August 2019; Accepted: 10 September 2019; Published: 12 September 2019

check for updates

\begin{abstract}
This article brings together the concepts of land and landscape, tightly linked in urban transformative situations, but rarely used for the purpose to strengthen strategic planning for sustainability. They are investigated as a combined base for land use deliberations, in early phases of planning processes, in practices of different scale, especially in a European context, drawing on planning and landscape policies generally agreed upon, as well as the UN Sustainable Development Goals. This article argues for taking into consideration the landscape as experienced human habitat, in relation to the understanding of land as both a common resource, and as pieces of property. This is motivated partly by the more or less global political trend and the turn from state interventions to individualistic capitalism (calling for new methods to solve common challenges), but also by a changing planning profession, increased collaborative planning processes, increased significance of public space as a scarce resource in densified cities, the need for holistic perspectives in sustainable urban development and the need for unifying concepts for urban and rural land at a local and regional scale. A new concept "around-scape" is suggested, in order to make visible the subjective binding between available perceived resources and spatial transformation.
\end{abstract}

Keywords: urban land use change; landscape; land properties

\section{Introduction}

The words land and landscape do not have the same meaning. At the same time, they are intimately related: can there be landscapes without land? Alternatively, are we instating some kind of land as an invisible 'bottom' of every landscape we see? In writing, reading and talking, we are frequently mixing and contaminating the meanings of land and landscape, thereby making it difficult to see their relationships, should this be important. The aim of this essay is to show this relationship, and at the same time explore what tools we can use to articulate this relationship.

Land is something relatively stable. It is different from sea and air since it does not float. It has an underground, however, with historical layers of different stability. Land is also a surface. It is not the same as soil or earth, but covers them both, literally. Land is, in general, two-dimensional (2D); it can be measured as an area. The contents of a landscape form together a three-dimensional (3D) function of a land area. A landscape has, contrary to land, an intrinsic unpredictability. It changes and grows, by natural forces (such as the photosynthesis, rust or water erosion) and by activities) of human societies and individuals (such as building houses and roads or planting seeds. Ever since the first settlers put down a fence, to protect the appropriated land, land areas have been measured, localized, controlled and protected. Later, land has also been localized in relation to the constructed global grid, which turned these areal properties also to be commodities possible to sell on a global market.

Land is sometimes used as equivalent to countryside; however, the city also consists of land plots. The activities taking place in each plot are, together with the activities taking place in other plots, shaping the urban landscape. The urban landscape is what we have around us, all individuals in their 
own way. It is shaped from private initiatives on single land plots and from authoritative initiatives on public land, such as streets, squares, parks and land reserves (land usually rented out, controlled by the rentiers as if it was private, but kept by, e.g., a municipality to give action space later). Even if few should argue against these descriptions of urban land and landscape, they are not commonly used as important assets, but more or less taken for granted. Land is owned. Landscape is around us.

The concept land use is crucial in a discussion of land and landscape. We can argue that landscapes are created or changed by land use, thus, how we use the land should determine what landscape we have. This is sometimes true, especially for very large estates. One estate, with a certain land use, can determine the landscape if it is big enough. It is, however, much more common that activities on many estates, more or less aware of each other, become a landscape, perceived by people from a position in the public space, or from their owned or rented land.

In most countries, a municipality (or similar administrative authority) is given the power of disposal of (thereby also the responsibility for) "common land", which are, e.g., streets, squares and parks. There is, however, a slow, but steadily growing practice of private actors who administrate publically accessible land, thereby in fact deviating from the concept of "public", since there is usually time (and other) limitations [1-3]. In this way, public space (in the meaning that no specific owner makes the rules for this space) is declining in cities. Urban public land is also being reduced by the densifying trend, possible by landowners, e.g., the municipality, selling out land for building purposes $[4,5]$. Thus, the ratio public land/private land is diminishing for two reasons. This affects urban landscapes in a manifold of ways. Sightlines are commonly getting blocked, less daylight is meeting the ground (more land areas are constantly in shadow), and orientation is aggravated due to landmarks and known direction lines being less visible. Natural features are getting scarcer, due to poorer conditions for plants. ("Eco system services" as a field of innovation is growing. Green roofs and green walls are commonly used as if they could replace natural areas on the ground, but neither roofs of walls are accessible more than to a very limited extent. This is why building consortia can claim "sustainable building" while critics call it "green washing" [6].)

The urban landscapes are also influenced by changes that are not just visual, but affect the perception of our environment in various other ways. The most common would be the direct effects of climate change, in terms of increasing amounts of storm water. Also here we see a double trend. Precipitation increases at the same time as the infiltrating land areas diminish in size. That land areas, properties and public space will be flooded more frequently in the future, is the most probable scenario for e.g., Nothern Europe, while severe droughts will make cities elsewhere uninhabitable. We will measure the damage in properties, while we as individuals will have to adapt, most likely by abandon the urban landscapes, either in favor of recreational landscapes outside the cities or in favor of virtual landscapes in computer games. In the virtual worlds it is totally clear when to navigate by the map (land, localization, measurements) and when to navigate by the landscape (visual layering, horizons and spatial relationships). We might need to learn from this clarity for discerning the meanings of land and landscape. To put it simple: There is no way to keep urban landscapes livable without putting demands on land (properties). So far, most of the 'urban sustainability discourse', the transdisciplinary research efforts and their application in cities, have taken place in public space. Only for the reason that public space is diminishing, it is not possible to keep this distinction between private and public businesses.

'Landscape' can be understood as a single interest and value; a view from one's window or access to (common?) land with high qualities increases the prize of the apartment, since it is perceived of as contributing to a more attractive, even healthier living environment. 'Landscape' can also be seen as a common interest and value, contributing to a healthy society on the more aggregated level, providing opportunities for car-free mobility and recreation, as well as space for social interaction or attractiveness for more business. There are, however, no absolute and general attributes to 'landscape', guaranteeing a more valuable, better, and more sustainable urban life. A landscape, if used in the sense "surroundings, perceived from a subject", cannot be defined as a set of objects, values or characteristics. 
It is certainly possible to focus or choose to make use of some extractions of a landscape, but to define it, you have to reduce and simplify the complexity it contains, with all its essentials, variations and relations. This simplification, however, cannot be made randomly and not without taking into consideration the different ways in which it is perceived and for what purpose. The European Landscape Convention (ELC) supports consideration of landscapes "as experienced by their users" [7], but this is seldom recognized more deeply than through pre-set 'landscape characterizations' [8]. Even if it as such sometimes fit into planning processes, it is hard to capture a landscape in a certain state; biological growth, erosion and other traces of time/aging are changing the qualities once measured in a landscape characterization spreadsheet to something completely different. Another problem with the landscape characterization assessments is that there are very few urban differentiations identified, as if urban landscapes always were the same. Apart from that this reveals an ecological disciplinary bias, such kinds of superficial landscape descriptions are not useful for detecting or discovering new or changed urban landscapes, but run the risk of conserving judgmental associations with urban landscapes, thereby hindering new landscapes to emerge, aiming at e.g., more just resource allocation as well as supporting social and cultural integration.

Landscape is a common affordance, hidden or open, private or public, perceived differently. It is always created by activities or decisions on the land areas which is part of or affect the perceived landscape. It is thereby impossible to-as the ELC states—consider the landscape in planning, design or management if there are no regulations to orchestrate the instruments playing the piece. The metaphor of landscape as a piece of music allows for the understanding of commonly provided experiences and pleasure, dependent on every single player's willingness to contribute. There will be no symphony from musicians refusing to follow the conductor's vision, sparing their instruments, checking instead for how much money can be made if they would sell or rent them out to someone else.

Not everyone owns real estate or land, but everyone has the right to use common land; allocated as roads and streets or urban public space such as squares, parks, playgrounds, etc. ("To have in common" means to share resources and contribute to their regeneration, sustainability or substitute. "The common" was in agricultural societies usually a piece of land, used by everyone, e.g., for grazing, with shared responsibilities but owned by none [9]. To secure the fulfillment of responsibilities, well-functioning commons have been institutionalized or regulated (even if only by habit), to avoid what has been called "the tragedy of the common" [10]; basically an over-use of a limited resource.)

At the countryside, accessible land at the countryside could be nature reserves or cultural parks. In England, there is a system of 'bridles', i.e., walking paths (originally arranged and used by district doctors). In some Nordic countries 'the right to public access' means that you can more or less freely move around by foot on others' land, as long as you are not causing damage, throw litter or disturb the owners. The different meanings and responsibilities connected to legal ownership, accessibility and use of land in a relatively stable society has not caused much confusion. In an increasingly urbanized and pluralistic society, however, conditions are constantly in flux. In an increasingly dense city, planning and building enterprise create faster and more profound changes in people's everyday surroundings; i.e., the urban landscape is changing with a pace and tempo not sensitive to any need of stability, should some people want this in their life. The public/private divide is not always relevant or applicable to frame people's living environment. The public space is largely being appropriated by restaurants and other commerce as well as by individual inhabitants and by the private space (real estates), which highly influences the character of the public space, acting as the "walls" of streets and squares, as defining social status of parks and sometimes ruling the connectivity of urban space by gating residential blocks formerly open to passage. "Land use" in a formal and legal sense, is a way to describe and define in what way authorities have used the information available connected to certain land. This land is divided in real estates, owned by somebody. Geological, meteorological and other facts connected to land areas and properties have since long been available and used to define land values. Geographical Information Systems (GIS) have increased the data accuracy on a detailed level and also opened for multipurpose, multifunctional and transdisciplinary analyses. The links between, 
e.g., ecological and sociological data, connected to specific land, on which, e.g., Ian McHarg put in lots of efforts in the 1960s [11], are now relatively simply computerized. This accuracy and efficiency is not enough, however, to understand how to combine these data with experiences and constant change, characterizing entireties, in order to improve ecological or sociological status in cities.

One further aspect needs to be mentioned concerning the change of rules for land value, land use and real estate business. Whereas land value increase or decrease in rural areas, most often, the value is determined from the natural resources of the estate (either directly captured, such as gems, ore or fossil fuels, or of indirect use, as with agriculture), in urban areas the value of the estates seem to be quite indifferent to any natural resources. It is, instead, the locations, the spatial specificities that are of significance. Thus, if the rural estate value lies in the properties on or under the surface delimited by the estate borders, the urban estate value is about relations to the context (the closeness to private and public functions and infrastructure, as well as all values potentially increasing if a building process is set in motion). Every decision of a change in land use, in the city as well as in the countryside, will potentially change also the landscape, as it is perceived. However, this never happens in a totally foreseeable way. The landscape is always something more than and different from the land.

\section{Landscape in Time, Space and Process}

As Hägerstrand argued long ago [12], time geography can include the understanding of parallel time-spaces changing with different pace. In urban settings, this is more a rule than an exception. Urban planning following general policies, politically decided, favors different functions, qualities and characteristics over time. The speculative dense building of the first half of the $19^{\text {th }}$ century resulted in misery and short lives for many. The social movements condemned this, leading to the accomplishment of a more sparsely built urban landscape, with street tree lines, city parks and gardens. Social reforms, combined with the increasing adaptation to car mobility, led to a zoned and fragmented landscape, hardly criticized from different viewpoints, pushing (again) for more dense structures, not least in order to save the agricultural land outside the cities. In the present densification trend, the urban landscape, thus also each human being's specific surroundings, is rapidly changing with every new building and land use change accomplished. The same high-rise building (realized by the landowner), built according to a specific development plan (decided by public authorities) can change the everyday landscape for many people and thereby their experience of their surroundings. Each building project affects the light/shadow conditions (Figure 1).

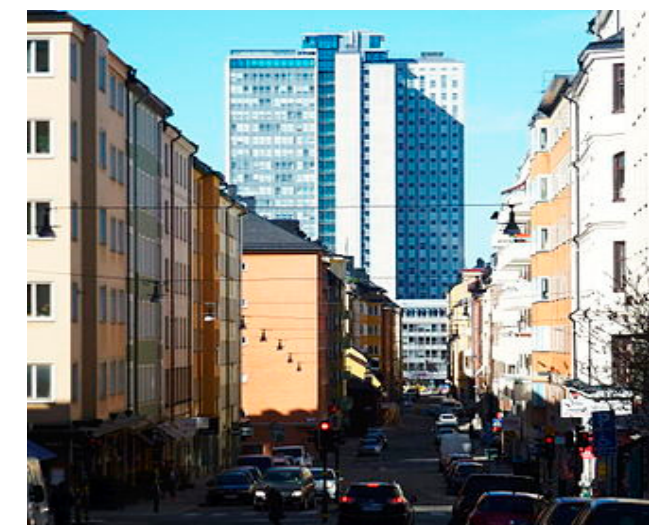

(a)

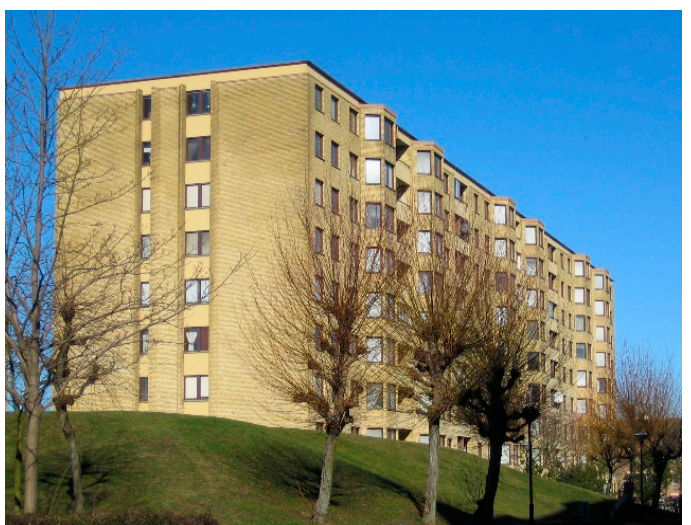

(b)

Figure 1. (a) Dense urban landscape, with floor, walls and open roof. The public space is in shadow. (b) Open urban landscape with vegetation as transparent curtains. Wandering light/shadow in the public space (Photos: PDM).

Constant shadow on the ground and in other buildings affect not only bodily experiences of warmth and chilliness, dryness and moisture (basic living conditions for all flora and fauna), but 
also socio-spatial as well as socio-material experiences [13], which are connected to the individual's relationship to society. Additionally, the boundaries between indoors and outdoors are significant for the urban landscape experience. A common difference between buildings in the city center and in the outskirts is the "inviting" function of the bottom floor for business purpose, which has the important side effect of many social meetings. In houses without "open" bottom floors, the outdoors seems desolated (in the picture exaggerated by the car traffic close by) (Figure 2).

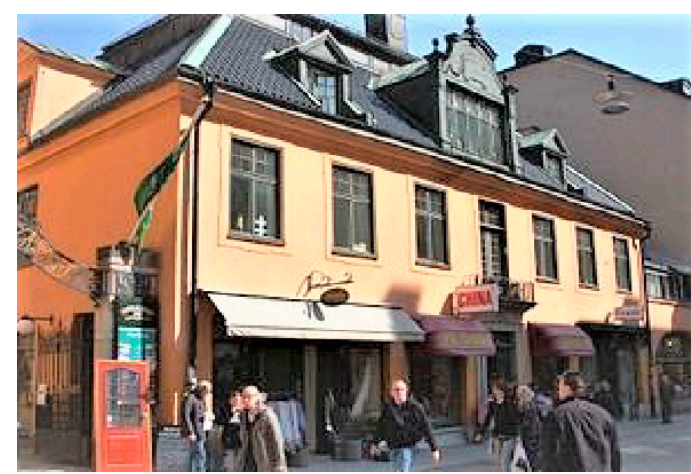

(a)

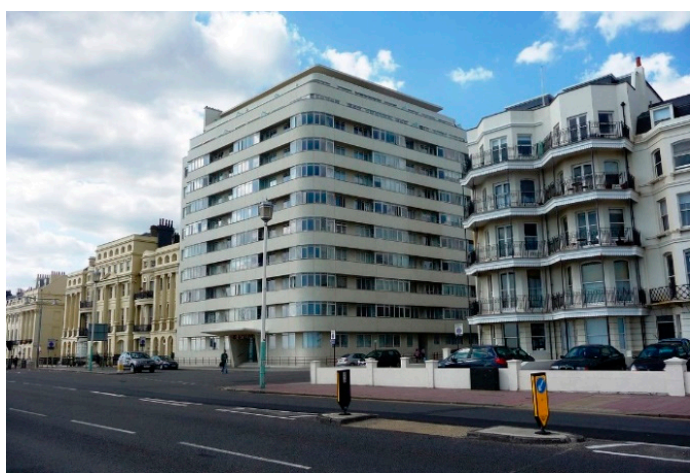

(b)

Figure 2. (a) Example of commercial bottom floors, encouraging mobility, encountersand commerce. (b) Example of residential bottom floors, creating anonymous, empty surroundings (Photos: PDM).

A third example of the consequences of the relationships between house and the ground is how public offices or service functions are designed and structured (Figure 3).

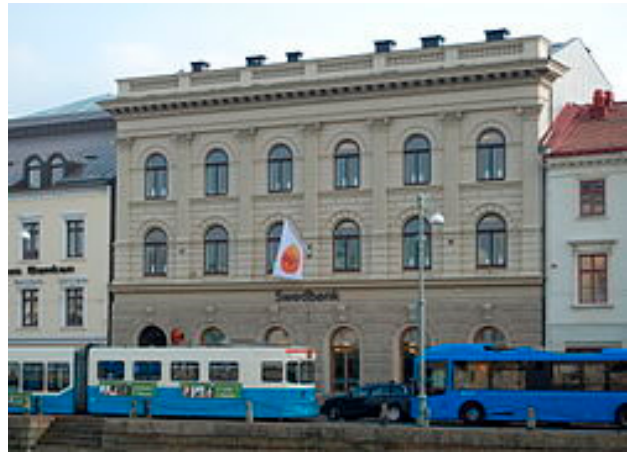

(a)

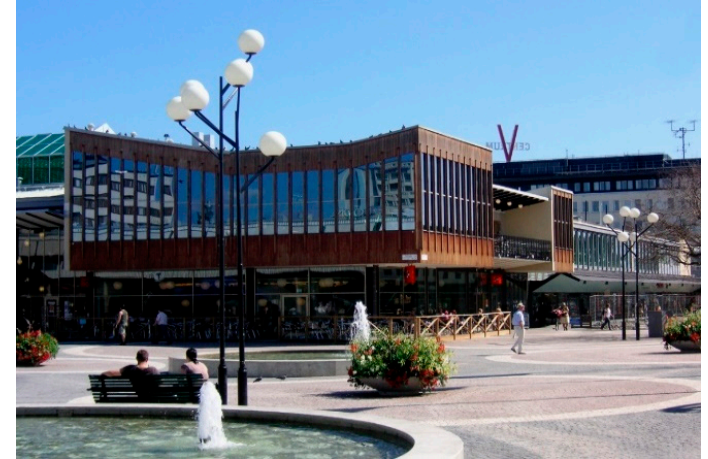

(b)

Figure 3. (a) House built for a bank in the 1890s, with a solid, almost repelling front. (b) Community center from 1950s, with public space, shops and bank services (Photos PDM).

Each of these characteristics (as well as other qualities) should be problematized and contextualized in an urban development situation; how does a change in density change the relationships between buildings and ground, how does it change mobility options and land use and how do the effects together change the landscape, perceived from the site?

With the aim to problematize the private/public divide as spatial signifier as well as open space as a common spatial resource, this paper takes a critical stand of the very concept of 'landscape'; not in order to criticize what landscape signifies and represent, but on the contrary for the purpose of highlighting and appreciate exactly these qualities. The word landscape is for historical reasons connected to vegetation and parks. More recently, "green infrastructure" (GI) has been used as a central planning concept, often following the definition of Benedict and McMahon from 2002: " ... an interconnected network of green space that conserves natural ecosystem values and functions and provides associated benefits to human populations." [14]. The downside of including landscape in 
planning terminology is that it loses most of its original meanings, i.e., views, sceneries and experiences of surroundings $[15,16])$. There is no easy way to use a concept in an unconventional way at the same time as you appreciate many of the qualities and benefits that the conventional use of 'landscape' in planning pursues. Neither is it easy to use much of the thinking from the field of landscape theory, and at the same time realize that the concept of landscape scuffs when used in urban settings. According to the ELC there should be made no difference in perspective between rural, urban and periurban landscapes; however, when it has become difficult to understand what the word landscape represents (in the urban), we may need new words that cover the 'landscape aspects and perspectives' we want to discuss and not something else.

In order to juxtapose discourses of land ownership and decisions on land use on the one hand [17], and ideas of "the right to the city" on the other hand [18-21], the word landscape is not sufficient, as long as it is used and conceived of as plants and green structures. The discourses of land and landscape do regularly meet in comprehensive planning and urban development practices [22], without, however, questioning the way property rights, accessibility rights, user rights and citizens' right are allowed (or not) to influence each other and cause frictions, related to urban development. As said before, in a stable situation, these spatial conditions (i.e., private/public and open/closed divides) are accepted and more or less inherited from one generation to the next. This is not the case in fast growing, urbanized regions, not only due to immigrants (from other parts of the country or from abroad). In a situation with increasing prices for apartments, an increasing amount of the apartments is being bought as an object of investment, not as a home. For example, a city could be built denser without being densified, achieving its official purpose (among which motives the environmental protection is the strongest), which is that people can live closer together, using less space and making it easier (financially and technically) to arrange public transport with good service. Furthermore, where an increasing part of the population needs to travel long distances on a daily basis (covering a vast land area), while having less and less open areas at disposal near their homes, because of urban densification, the relationship to one's surroundings becomes spatially dissociated. The discourses of place attachment, e.g., on the importance of open space and play areas near home, or the discourse of GI, e.g., the importance of a short distance to the nearest green space, are becoming more and more complicated and problematic. Just as "urban" and "rural" are getting obsolete as concepts describing a landscape, the difference between "home spaces" and "visited spaces" becomes blurred. Place- or site-related qualities are just exceptionally cross-disciplinary described. This is why e.g., access to green spaces can be proven to be important for enhancing people's health and wellbeing; at the same time, the greenest residential areas are proven to contain inhabitants with the shortest life length compared to other areas in the same city [23].

If urban planning in the future should be able to consider common interests, it could not be delimited to act in "evidence based" ways [24], as long as these evidences are delimited to disciplinary formulated questions. Instead, it is important to find ways to produce and use meta-evidence, i.e., syntheses of site-specifically relevant knowledge (The word 'meta-evidence' is not established with a defined meaning, but scholars engaged in transdisciplinary theory are more and more thinking of 'meta-' terms [25], in order to label clusters of variables, put together for a certain purpose or experienced in a certain context.)

. The word "landscape" has potential, as an elastic, scale-flexible concept, to be used as the concretizing reference for such syntheses. Landscapes could be analyzed and evaluated as its components, but never understood without also adding the entirety. To understand and communicate the perception, conception and potential change of a landscape, you have to state from which position this landscape is viewed as a whole (the viewpoint both as location and perception). It might be possible to use "site" in a way including both the viewpoint(s) of the landscape and as property. It could also be-maybe more interesting in a digitalized world-that landscape change is mapped in GIS, in a grid connected to experiences from every pixel (regardless of ownership). There are many ways to connect the experienced surroundings and the divided land. This article is not going into 
methods (artistic or scientific) for this purpose; it just aims to indicate the importance of a joint vision upon the continuous (landscape) and the discontinuous (land property) perspectives as foundations for the use of, and the resilience of, our human habitat.

\section{New Contexts for Landscape Concepts}

In a recent essay, published in this journal, Burley presented the background for the trend of landscape urbanism (L.U.), using the word "normative theory", as a label for professional trends [26]. Landscape urbanism as a normative theory, is equal to the movements "city beautiful", "garden city", etc. in this respect. Although L.U. has been claimed to have theoretical foundations [27] the theoretical framework is hard to sort out [28], while instead some iconical projects have set the norm for what L.U. "is".

One intellectual advantage with this rhetorical categorization is that the normative theory is not mixed with either theory (disciplinary/interdisciplinary/transdisciplinary logics) or megatrends like modernism, post-modernism and post-post-modernism (discursive concepts crossing all sectors and disciplines, as labels of periods or spirits of time). Burley makes clear and understandable that L.U. draws from several theoretical directions, is connected with post-post-modernism, but owes its historical roots both to modernism and earlier trends and normative theories. After being a highly influential buzzword for around a decade, it is probable that even if L.U. as a labeled concept might have had its peak, some if its ideas and practices will be more lasting. We are witnessing not only a widening and increasing field of landscape architecture, but also a growing understanding and incorporating of landscape perspectives in adjacent fields, such as architecture, spatial planning and visual arts, although with other cultural and ideological layers. Using wording from the cultural sociologist Pierre Bourdieu, the "habitus" of landscape professions has become diverse. The urban spatial professions have adopted (or are trying to adopt) "landscape as a lens for the urban" [27], but in different ways.

One of the most influential trends within "sustainable planning" is to elaborate on urban "green infrastructure" as well as "blue-green infrastructure". This is indeed to strengthen the urban as the human habitat, for a lot of reasons and it is often argued to support a sustainable development (contributing to at least ecological and social improvements); however, "green infrastructure" is not always used in a professionally sound way to describe what is actually planned and built [16]. Moreover, it is certainly not possible to determine in what way green infrastructure influences the urban landscape. Vegetated areas are functional in a number of ways, sometimes called "ecosystem services", but this is not the same as claiming improvement of the urban landscape.

One of the most neglected aspects of the urban landscape is its continuous long-term evolvement, be it adding artifacts, maintenance and articulations of built and grown environments, or just natural forces. Most urban visions are just visions for a property, a block or a district. Even Robert Moses was excluding many parts and aspects of the urban landscape when, as a mayor of New Your City in the 1960s, he created a vision as a physical model of Manhattan, obsessively controlling that what was built was built as the model prescribed [29].

The European Landscape Convention states that the landscape should be defined as its users perceive it, which should be taken into consideration in planning, land use and land management. The way of implementing the ELC by "landscape characterization" has, however, thus far not facilitated any potency of significance of the landscape concept in urban development and planning. (There is no question about the ELC's influence when it comes to adding green elements and ecosystem services to planning policies, however, I have not found signs of a landscape perspective where the surroundings of inhabitants in different districts are included.

A plausible explanation is that there has not so far been any relativization between the holistic concept "landscape" and the parts it necessarily consists of the areas, i.e., the properties or (in theory) some other way to define areas of land.

The landscape is how every individual perceive and conceive of her/his surroundings (as an entirety from a viewpoint or as surroundings of a place or movement). The (land) area is how every individual 
piece of land is localized and connected to other areas in a measurable way. The landscape is not measurable, since it can never be exactly defined what specificities that are actually parts of this landscape, produced as it most often is, in mobility. However, the constructed, stable land structure consists of land areas, i.e., properties. The changes in a landscape always have origin in land areas. There is no outside of the land areas involved in a landscape. This is easy enough to understand but hard to remember and conceptualize, especially in an urban landscape where most of the land (even nearby) is invisible, free view shielded by buildings of different heights.

The fact that there are plenty of dysfunctional urban landscapes (abominable to look at, impossible to use for recreative purposes, not contributing to eco-system services, etc.) should not stop us from using 'landscape' (or what the word represents) as a mode of description and analysis of cities. 'Landscape' is by necessity an inclusive, multidisciplinary concept, entangling social, environmental and economic factors in the same weft. It is also weaving together habitually divided concepts like urban/rural, private/public, nature/artifact, to name a few. Last, but not least, 'landscape' is a concept in need of further investigation, to discover in what ways, with what measures, it is possible to make the everyday surroundings of all the urban inhabitants something that matters, in planning activities for a sustainable urban development. It already matters to people. We can read this in the higher costs and profits connected with appreciated urban landscapes. This is, however, an exclusive way to use the concept of landscape. We have not yet learned how to use this inclusive concept of landscape to its full potential. We have not unveiled how to create good living conditions for all urban citizens, how to avoid segregation and diminish the clustering of the privileged and those who are not. The hypothesis scrutinized here is that landscape distinctions, trespassing property boundaries, could be useful in making decisions on urban development, building sustainability arguments not only as a measure of density, green and digitalization, but also displaying "the unmeasurable", the opportunities for landscape experiences.

Within the planning discipline, landscape as an interdisciplinary perspective has been more or less avoided, in favor of legal, social, environmental, technical and other disciplinary perspectives and interests [15,27], except for in the limited sense landscape, i.e., green areas and structures, lately GI (Green Infrastructure). There is, however, an increasing need of concepts and words for entireties and syntheses, fostering transdisciplinary, holistic and collaborative thinking [30]. We already currently experience urban development trends, driving the necessity to find and use concepts and words possible to use for handling future entireties, which are not necessarily the same entireties we have managed up until today. "Smart cities" or "green cities" claim to be holistic, but only in the sense that one asset (digitalization or vegetation) imbues the whole city. This trend of finding new inclusive concepts for urban development could gain from starting a more critically inclusive track, complementing the more or less totalitarian concepts (in the sense that neither "smart" nor "green" is open to or attracts knowledge and collaboration as exchange of ideas, visions and methods).

The exchange of spatial dichotomies (e.g., public/private space) for spatial gradients, and the exchange of a general divide between the urban area and countryside for "socio-material densifications" [13] allow for juxtaposing and to weave together areas with different spatial character and differently distributed resources and services. We need to understand how one specific urban area entangles with its surroundings and how a region not only consists of a gradient from less to more densely populated areas, but also varies in other, entangled, quantitative and qualitative terms [31]. We also need to understand in what sense these entanglements are temporary and will change due to global economic trends and political decisions on different levels, but also as local economies and spatial agreements. Additionally, in this context, dichotomic thinking as well as habitual associations (e.g., linking local trading to slow development) can be counterproductive to finding sustainable and resilient alternatives in different decision situations. In market driven planning and building [32], it is not less but more urgent to find evidence-based arguments, as well as alternative design and syntheses, for collaborative methods and guidelines for how to include, explore and develop urban landscapes in planning. 
The material and spatial qualities fostering sustainable urban development, both as living environments suitable for new life styles and as common resources encouraging resilient urban solutions, are only to a small extent valuable as singularities-they need to be contained in a common landscape. This is the entity in which it should be possible both (for everyone) to perceive significant changes in one's surroundings and (for planning authorities) to measure and estimate the change of common values as consequence of urban development, i.e., the increase of urban density. The opportunity to make informed choices is now taken for granted in the rich parts of the world, as part of the global trade and economy, and as an aspect of individual freedom. In the 20th century, however, we have witnessed a vast and consequent transposition in both the cities and the countryside, from roads and streets with a mix of vehicles and pedestrians (and with a variety in width and qualities), combined with an expanding railroad net, to a streamlined transport infrastructure more or less completely serving ever-expanding car traffic. The individual freedom, connected with an own, fast vehicle, soon became a passion. However, the common infrastructure construction, making the passion of the individuals realizable, has in many places accomplished a nightmare of congestions and air pollution, people finding themselves trapped in lines instead of living their dream of freedom. This is maybe the most flagrant example of how the consequences of disregarded landscapes, through structural changes, can appear as a surprise.

A strong link was forged between the private car mobility and the urban sprawl of one-family houses leading to widespread suburban areas. In the United States, this was already happening in the middle of the 20th century, causing a decline of city centers, resulting in the so-called doughnut cities [33], a development much later experienced in Europe and still on-going, caused by the increase of internet shopping and the localization of external malls, leaving the historic city centers more or less as museums. This was not a strategically planned development, but rather a consequence of 'the tyranny of small steps' [34]. No one wanted an empty city center, but everyone wanted their own house with a garden and at least one car per adult person to be able to leave the house and move around freely. There are exceptions, as in the city of Vienna, where a diverse public transport system, combined with strict policies for affordable housing and regulations of the real estate market, seem to be able to hinder or at least slow down gentrification, segregation and city center degradation. Perhaps cross-sectorial systems, informed by transdisciplinary urban landscape studies, would be able to find ways of making changes of urban landscapes in accordance with high common landscape values, instead of urban landscapes becoming different as a result of planning and building processes not taking these urban landscapes into consideration.

The all-permeating transport infrastructure has not only facilitated a manufacturing and trading system, thus far dependent of fossil fuel. It has also created a fragmented landscape where every activity and every experience is down prioritized in comparison to transport. There has, over the years, been very little of political discussions concerning the main ambition, the fully organized and extended transport infrastructure. The voices concerned by the landscape changes caused by the extension of the road systems have not been listened to. Instead, when ecological concerns reaches the authorities, siloed thinking has led to at best effective but technically narrow solutions for landscape connectivity in very specific ways; it may be a bridge over a road for hazel mice to meet and mate, or a tunnel for frogs to move between waters $[35,36]$ (see Figure 4); important, but not close to anything all-inclusive. An urban resilient landscape cannot be constructed out of lists of particularities [37], but should rather be built on entireties synthesized by linking these particularities together, within an urban landscape. This is why it is necessary to think in a transdisciplinary way to solve these issues. Scientific evidence alone will not show fruitful paths, but has to be collaborated within the other disciplines, actors and driving forces in landscape practices. These practices are built on societal demands, such as building of dwellings for new urban citizens; however, they are also carried through as requirements and rules for landowners and municipalities. 


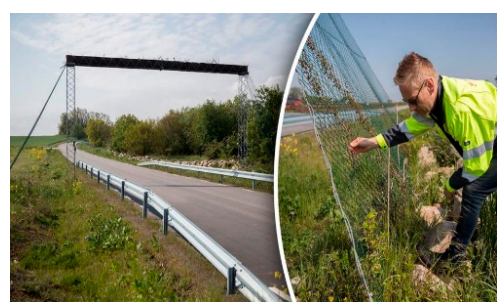

(a)

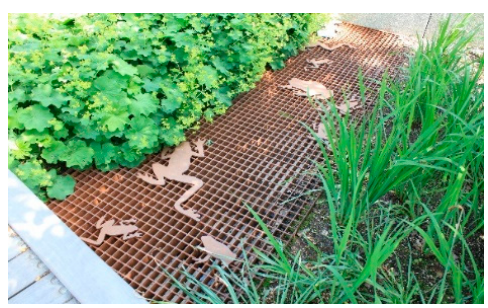

(b)

Figure 4. (a) A new road (serving an urbanized countryside) destroys the domain of the protected hazel mouse. To mitigate the effect, the traffic board installed a bridge for the mice to use. Two years after installation, the vegetation is not sufficient to make the bridge work as intended. (Photo: Skåne County Council website, visited 2019-05-30). All rights reserved) (b) To keep the rules for biodiversity in the National City Park in Stockholm, when building an adjacent dense urban district, a frog tunnel must be constructed, to allow frogs to move freely under streets and between and inside raingardens and ditches. (Photo: SWECO website, visited 2019-05-30).

\section{Property Value Increase-from a Land Perspective to a Landscape Perspective}

The elephant in the room is very seldom the subject of discussion. Even if we all know that one of the most powerful driving forces in urban transformation is property value increase, this is not talked of as a variable in societal planning, but is rather an axiom. This would all be for the good, were it not for the bottom line that a leading tendency is to increase the property value to maximize profit for the landowner. There are obviously other ways of increasing the values of properties, including the public perspective. The rules for land ownership could (and has been) changed. The alternatives to private ownership as a lottery game are numerous; ownership could be tied to a responsibility of ecological value increase, to societal goals for integrated population or it could have a time limit with a financial framework leading to a win-win situation. Creativity within the game of maximizing profit, has thus far been fully accepted without restrictions for the consequences of actions, with few exceptions. EIAs (Environmental Impact Assessment) is one such example, effective in land use planning. An EIA is in some countries mandatory for builders, private and public, to provide before a plan can be legalized.

Another planning tool, showing way to put demands on land owners and builders, more and more used in Northern Europe, is the so-called "green factor", with points for increasing ecological values, used in the competition for building permits. We need both responsibility and alternative thinking, not just in policy documents and visionary plans, but also among the actors building the human habitat: the cities.

Property value and land value are more or less synonyms. Property value and landscape value are more difficult to weigh against each other and to speculate around. If we play with the thought that every property value increase must be followed by a landscape value increase, this would maybe change something in the thinking on urban development. Landscape is individual, but also public.

To exemplify, a simple but very significant value of a location is the light-shadow circumstances. In some places (during e.g., the strong functionalist period in Sweden) there are rules for the amount of daylight in an apartment. In outdoor environments, this is even more important [38]; however, since light does not follow property boundaries, it is harder to regulate. Today's urban development is often so dense that the sunlight does not reach the ground (see Figure 1). A rule about a minimum of sunlight on the ground in residential areas would influence building density and diminish the profit for the owner, but increase the landscape value quite a deal.

To sum up, the frontier line is drawn between the experienced right to have a say of one's surroundings (this is actually a paragraph in the convention of human rights) and the lawful right to do exactly what you want to do with your (by law acknowledged) property, including keeping other people outside of it. (More and more urban blocks, earlier functioning as passages, linking districts and streets, are now gated, the official argument being for safety reasons.) The right to make a profit from 
what you have once (by inheritance, by theft or by purchase) become the owner of, is not regularly questioned. Instead, it is taken for granted.

Everyday landscapes (the surroundings, following a subject) and landscape biography (how these surroundings have changed through history) has, to a very little extent, been taken as relevant for planning. How can the very unique landscape experience (and the right to it, according to ELC) be something relevant or even possible for common and public actors to engage with? Is landscape not just a story, for everyone to tell in their own way? Is the future of landscape anything more realistically elaborated on, than e.g., speculations of what is going to happen tomorrow?

There are two ways to answer this question. If, by a landscape perspective in planning, you are sure to achieve good urban landscapes to live in, the answer is no. A landscape perspective does not necessarily afford an easy way to resilient urban landscapes or to landscapes of equality. However, if you rephrase the question to "Can a landscape perspective be helpful when trying to create resilient and just urban landscapes?", the answer is yes. This is landscape urbanism, as claimed 15 years ago by Charles Waldheim "landscape as a lens" [26]. This lens is needed to widen the scope in planning, from one building or one block to the surroundings, the sceneries and the experienced environments. It will never be a lens for discovering particularities or essentials. There are lots of different valuable, appreciated landscapes and landscape aspects: not one is "the best". There is simply no 'best' practice when it comes to landscape, as long as you are talking of the landscape 'itself'. What we can talk about when referring to planning and landscape is partly process (it could be stated that one or more phases during the planning process elaborate on landscape change), and partly collaborative learning and experience.

\section{Representations of New Urban Landscapes}

I have argued, partly with support of the ELC [8] that the landscape perspective should be included in urban planning, in early stages, to include the landscape change in the deliberation of alternative urban developments. What would this be worth then? Why would the world improve with a landscape perspective included in urban planning? Evidently, this is not necessarily the case, just as urban planning at large does not guarantee a better city than one that is more spontaneously accomplished, or rather a laisser-faire-situation. Representations of landscape play a crucial role for what is actually built, rebuilt or constructed, and what is deliberately not built but managed as open space with or without vegetation, allowed or planted. Without landscape representations, we are not able to understand the effect a new building or even system will have on the existing surroundings. Furthermore, we need both a map, to understand the two-dimensional context with a birds-eye view, and a perspective visualization, to understand the two-dimensional context with a human-eye view. What we also need is a frequent shifting between these perspectives. This is an important part of the professional training of landscape architects to learn to swiftly change between maps and perspective visualizations, building knowledge and understanding by adding and changing between different sources of information, expressed in 2D pictures and 3D models. The significance of the training of this ability is not the increased information per se, but its expressions by a subject that will be the base for the deliberations and realizations in the planning and design processes.

Architectural competitions in urban development can be judged in many ways (dependent not only of the entries, but also of the jury members), but in the end, the result will reward the best representation of an urban landscape. (Here, there is certainly a need for a debate on what is "the best" representation: is it a result of what is judged as providing "the best pictures"; most beautiful, most clarifying, most distinct and detailed, etc.; or evaluated by the trained eyes of jury members spotting what is going to be "the best landscape" (most beautiful, most livable, most functional, most sustainable, etc..)

Therefore, urban planning would benefit from a landscape urbanist thinking; i.e., construct protocols for evaluating not only items, materials, volumes and other measurable criteria, but also for entireties, relations, manifoldness and the contents of the surroundings. How this should be done is 
certainly an important issue, which is not discussed here, partly because this issue has to, by its nature, be discussed in local conditions, to consider what is important in a certain social, environmental, economic and political context.

\section{Concluding Discussion and Suggestion: From Ownership Rights to Land Value Increase, With an Urban Landscape Perspective, Using a New Concept-"Around-Scape"}

Our brains store and calculate incoming information, mostly in ways we cannot yet understand in a logical, communicative way. Still, this subconscious storage seems to influence our ways to react, feel, trust and affect our surroundings, including co-inhabitants of human or other origin. In spite of our adoration for scientific evidence, we more often than not trust our "gut feeling", even to the point where you have to go beyond scientific evidence. Quoting Jean Piaget: "When a new experience makes you doubt your thoughts, you have to re-arrange your cognitive structures, opening new opportunities for understanding" [39]. "Gut feeling" is very problematic as statement in an argumentative discussion, but few would nevertheless claim that they never let their gut feeling rule over available evidence. In relation to landscape perspective, it seems reasonable both to trust general, scientific information and to trust valuable own experience, especially concerning landscapes from which you actually might have unique information, from deep and frequent involvement.

As a consequence of the insecurity we feel due to climate change, migration, geological dynamics, etc., we are watching a growing demand for risk calculation as well as preparatory actions in case of crisis. A "best-practice-certificate" can be seen in this perspective as one of many attempts to achieve safe urban development, not to build in problems which could have been avoided. However, since best-practice-solutions tend to be delimited to technical innovations in the building sector (e.g., devices for energy-, water- and heating- measuring), they are sometimes irrelevant for the urban landscape scale. As Lister has argued [40] the business' understanding of "scaling up" is not applicable to natural forces. With the growing knowledge of urban ecosystems [41] we have thus far only partly understood how natural functions and artifact functions can perform together (without jeopardizing the natural in a long-term sense).

A growing body of research has questiond the use of modernistic masterplans, doubts "best practice"-solutions and argues instead for urban transformation models rooted at site and developed in succession, regarding the context-specific scale in which different issues of urban change have to be dealt with in different ways [42,43]. A landscape lens in planning would be able to incorporate such models as well as others. What is added here is the idea to erase the frontier between private and public land issues, admitting the collaborative game they will have to be played out in, should we succeed in creating a sustainable habitat for human beings (and other organisms).

Very few have asked for a "landscape perspective" in planning $[15,28]$. Thus, this is not anything derived from some participative process; neither is it anything concluded from the ELC, but it has been put forward in discussions on urban transformation since Geddes' mid-19th century, by Ian McHarg's mid-20th century and more broadly and interdisciplinary outlined, by the landscape urbanists of the early 21st century. The landscape perspective in urban planning is a theoretically constructed concept; however, it is related to a series of landscape perspectives, from different disciplines, and-most of all—expressed in landscape representations, without which we are not able to express, discuss or take decisions on why, how, when and by whom our urban landscapes should be affected by its inhabitants, in terms of management and planning, design, building and maintenance. From this, together with the confusion connected to many interpretations of the word landscape [44,45], I have drawn the conclusion that we need another complementary word to use for landscape perspectives in urban settings.

Perhaps we need a new word for the concept discussed in this paper, with the intention to make visible and to be able to take into account the surroundings of urban inhabitants in urban transformation and planning. Probably, "landscape" or "urban landscape" is not enough. These are words that have been used for ages, without influencing urban design or planning significantly, 
not even when labeled as landscape urbanism. Are there some dominating (historic and cultural) landscape discourses, obscuring the sight for discovering new meanings? Landscape has definitely has different meanings in different times. However, is it meaningful to use 'landscape' again, with a new meaning? Perhaps it makes better sense to suggest a new word, for a concept partly coherent with older meanings of "landscape" [46], but connected more closely to the subject than these. This word should also connect personal experience to public space. This is actually been done before, by the mentioned geographer Torsten Hägerstrand. He has suggested, in Swedish, that the word "omgivning" (in Engl. "surroundings") should be exchanged for "givning" (in Engl. close to "the meaning you give to what is around you") [47]. Preliminary, "around-scape" is suggested as the word to signify the surroundings of a subject, while at the same time avoiding private property to measure this personal space. Rather, the manifold of around-scapes should inform the planners and designers, making them more competent to handle the management of urban space in a way suitable for people living there, as well as people visiting, as well as children of the future.

Funding: This research received no external funding.

Acknowledgments: My gratitude goes to the Dept of Landscape Architecture, Planning and Management, SLU, for allowing the hours for this work.

Conflicts of Interest: The author declares no conflict of interest.

\section{References}

1. Abramson, A.; Theodossopoulos, D. Land, Law and Environment: Mythical Land, Legal Boundaries; Pluto Press: London, UK, 2000.

2. Blomley, N. Land use, planning, and the "difficult character of property". Plan. Theory Pract. 2017, 18, 351-364. [CrossRef]

3. Needham, B.; Buitelaar, E.; Hartmann, T. Planning, Law and Economics. The Rules We Make for Using Land; Routledge: New York, NY, USA, 2018.

4. Low, S.; Smith, N. The Politics of Public Space; Routledge: London, UK, 2006.

5. Mitchell, D.; Attoh, K.; Staeheli, L. Whose city? What politics? Contentious and non-contentious spaces on Colorado's Front Range. Urban Studies 2015, 52, 2633-2648. [CrossRef]

6. De Block, G. Ecological infrastructure in a critical-historical perspective: From engineering 'social' territory to encoding 'natural' topography. Environ. Plan. A 2016, 48, 367-390. [CrossRef]

7. Council of Europe. The European Landscape Convention. 2000. Available online: https://rm.coe.int/ CoERMPublicCommonSearchServices/DisplayDCTMContent?documentId=0900001680080621 (accessed on 5 August 2019).

8. Fairclough, G.; Sarlöv Herlin, I.; Swanwick, C. Routledge Handbook of Landscape Character Assessment: Current Approaches to Characterisation and Assessment; Routledge: London, UK, 2018.

9. Gidwani, V.; Baviskar, A. Urban Commons. Econ. Political Wkly. 2011, 46, 42-43.

10. Hardin, G. The Tragedy of the Commons. Science 1968, 162, 1243-1248.

11. McHarg, I. Design with Nature; Doubleday/Natural History Press: New York, NY, USA, 1969/1994.

12. Hägerstrand, T. Decentralization and Radio Broadcasting: On the 'Possibility Space' of a Communication Technology. Eur. J. Commun. 1986, 1, 7-26. [CrossRef]

13. Østerberg, D. Stadens Illusioner: En Sociomateriell Tolkning av Oslo (The Illusions of the City: a socio-material interpretation of Oslo); Korpen: Gothenburg, Sweden, 2000.

14. Benedict, M.A.; McMahon, E.T. Green infrastructure: Smart conservation for the 21st Century. Renew. Resour. J. 2002, 20, 12-17.

15. Lindholm, G. 'Visible gestures': On urban landscape perspectives in planning. Plan. Theory 2012, 11, 5-19. [CrossRef]

16. Lindholm, G. The Implementation of Green Infrastructure: Relating a General Concept to Context and Site. Sustainability 2017, 9, 610. [CrossRef]

17. Blomley, N. Unsettling The City: Urban Land And The Politics Of Property; Routledge: New York, NY, USA, 2004. 
18. Lefebvre, H. The Production of Space; Nicolson-Smith, D., Translator; Blackwell: Oxford, UK, 1974/1991.

19. Harvey, D. The Right to the City. Int. J. Urban Reg. Res. 2003, 27, 939-941. [CrossRef]

20. Mitchell, D. New Axioms for Reading the Landscape: Paying Attention to Political Economy and Social Justice. In Political Economies of Landscape Change. Places of Integrative Power; Wescoat, J.L., Jr., Johnston, D.M., Eds.; Springer: Dordrecht, The Netherlands, 2008; Volume 89, pp. 29-50.

21. Innes, J.E.; Boher, D.E. Collaborative rationality as a strategy for working with wicked problems. Landsc. Urban Plan. 2016, 154, 8-10. [CrossRef]

22. City of Malmö (Sweden). Översiktsplan för Malmö. Planstrategi (Comprehensive Plan for Malmö. Plan Strategy, English Summary). 2018. Available online: https://malmo.se/download/18.cb832751656711ccfb1673/ 1535372065627/OP_english_summary_lores.pdf (accessed on 5 August 2019).

23. City of Malmö (Sweden). The Malmö Commission. "Malmös väg mot en hållbar framtid: hälsa, välfärd och rättvisa" ("Malmö's way to a sustainable future: health, welfare and justice"). 2013. Available online: https://malmo.se/download/18.1d68919c1431f1e2a96c8e4/1491298331527/malmo\%CC\% 88kommisionen_rapport_engelsk_web.pdf (accessed on 5 August 2019).

24. Davoudi, S. Resilience and governmentality of unknowns. In Governmentality after Neoliberalism; Bevir, M., Ed.; Routledge: New York, NY, USA, 2016; pp. 152-170.

25. Nowotny, H. Rediscovering Friction: Not All That Is Solid Melts into Air. In The Necessity of Friction; Åkerman, N., Ed.; Routledge: New York, NY, USA, 2018; pp. 287-312.

26. Burley, J.B. The Emergence of Landscape Urbanism: A Chronological Criticism Essay. Land 2018, 7, 147. [CrossRef]

27. Waldheim, C. A Reference Manifesto. In The Landscape Urbanism Reader; Waldheim, C., Ed.; Princeton Architectural Press: New York, NY, USA, 2006; pp. 013-019.

28. Vicenzotti, V. The landscape of landscape urbanism. Landsc. J. 2017, 36, 75-86. [CrossRef]

29. Kahn, A. Imagining New York. In The Urban Lifeworld: Formation, Perception, Representation; Madsen, P., Plunz, R., Eds.; Routledge: New York, NY, USA, 2002; pp. 237-251.

30. McCormick, K.; Anderberg, S.; Coenen, L.; Neij, L. Special Issue: Advancing sustainable urban transformation. J. Clean. Prod. 2013, 50, 212. [CrossRef]

31. Tietjen, A. Towards an Urbanism of Entanglement-Site explorations in polarised Danish Urban landscapes. Ph.D. Thesis, Aarhus School of Architecture, Aarhus, Denmark, 2011.

32. Remøy, H.; Street, E. The dynamics of "post-crisis" spatial planning: A comparative study of office conversion policies in England and The Netherlands. Land Use Policy 2018, 77, 811-820. [CrossRef]

33. Juday, L. The Changing Shape of American Cities; Report; Demographics Research Group, Weldon Cooper Center for Public Service, University of Virginia. 2015. Available online: https://demographics.coopercenter.org/sites/demographics/files/ChangingShape-AmericanCities_ UVA-CooperCenter_February2015.pdf (accessed on 5 August 2019).

34. Kahn, A.E. The tyranny of small decisions: market failures, imperfections, and the limits of economics. Kyklos 1966, 19, 23-47. [CrossRef]

35. SWECO. Hasselmuspassagen (The Hazel Dormouse Passage). 2017. Available online: https://www.sweco. se/vart-erbjudande/projekt/hasselmuspassagen/ (accessed on 5 August 2019).

36. Stockholm County Council. Grodtunnel byggs i Norra Djurgårdsstaden (Frog tunnel is being build in StockholmRoyalSeaport). 2016. Available online: http://www.nationalstadsparken.se/default.aspx?id=5980\& ptid $=0$ (accessed on 5 August 2019).

37. Sörlin, S.; Warde, P. The Problem of the Problem of Environmental History: A Re-Reading of the Field. Environ. History 2007, 12, 107-130. [CrossRef]

38. Edwards, L.; Torcellini, P. Literature Review of the Effects of Natural Light on Building Occupants. Technical report. OSTI. (U.S. Department of Energy Office of Scientific and Technical Information). 2002. Available online: https://www.osti.gov/biblio/15000841 (accessed on 5 August 2019).

39. Davidson, P.M. Piaget's Category-Theoretic Interpretation of Cognitive Development: A Neglected Contribution. Hum. Dev. 1988, 31, 225-244. [CrossRef]

40. Reed, C.; Lister, N.-M. Ecology and Design: Parallel Genealogies. Places J. 2014. [CrossRef]

41. Savard, J.P.L.; Clergeau, P.; Mennechez, G. Biodiversity concepts and urban ecosystems. Landsc. Urban Plan. 2000, 48, 131-142. [CrossRef] 
42. Jarzombek, M. A Green Masterplan is Still a Masterplan. In Urban Transformation; Ruby, I., Ruby, A., Eds.; Ruby Press: Berlin, Germany, 2008; pp. 22-29.

43. Diedrich, L.; Dahl, C. Ile de Nantes 2000-2010: a method for the meantime? J. Landsc. Arch. 2016, 11, 72-83. [CrossRef]

44. Jones, M. The elusive reality of landscape. Concepts and approaches in landscape research. Nor. J. Geogr. 1991, 45, 229-244. [CrossRef]

45. Meinig, D.W. The beholding eye: Ten versions of the same scene. In The Interpretation of Ordinary Landscapes: Geographical Essays; Meinig, D.W., Ed.; Oxford University Press: New York, NY, USA, 1979.

46. Cosgrove, D.; Daniels, S. The Iconography of Landscape: Essays on The Symbolic Representation, Design and Use of Past Environments; Cambridge University Press: Cambridge, UK, 1988.

47. Hägerstrand, T. Att äga rum, (in English this would equal: "To take place"). Sv. Geogr. Årsbok 1997, 73, 105-112.

(C) 2019 by the author. Licensee MDPI, Basel, Switzerland. This article is an open access article distributed under the terms and conditions of the Creative Commons Attribution (CC BY) license (http://creativecommons.org/licenses/by/4.0/). 